\title{
EMANUEL SCHINDLER - THE LAST OF THE PROPONENTS OF HISTORICAL SCHOOL IN THE NATIONAL ECONOMIC THEORY
}

\author{
[Emanuel Schindler - poslední ze stoupenců metody historické školy v \\ národohospodářské teorii]
}

\author{
Kamil Fuchs ${ }^{1}$ \\ ${ }^{1}$ Mendelova univerzita, Provozně ekonomická fakulta, Zemédělská 1, 61300 Brno \\ Email:kamil.fuchs@mendelu.cz
}

\begin{abstract}
In 1919 the town of Brno became a higher education centre. The twenty years' tradition of the Czech Technical University in Brno, where Karel Engliš, an Albín Bráf's pupil, worked from 1911, was followed by new established universities in Brno, Masaryk University and Czechoslovak University of Agriculture. It was the Faculty of Law at Masaryk University, where the economic education was systematically developed. The economic theory here vas based on Engliš's teleological method. The role of Masaryk University, as well as of Karel Engliš, is recorded and processed in detail. However, the fact that remarkable personalities engaged in economic education at Czechoslovak University of Agriculture as well stayed away from attention. The article presents economic opinions of Emanuel Schidler, another Albín Bráf's pupil, who remained faithful to the historical method.
\end{abstract}

Keywords: austrian school, czech economic thinking, historical method, historical school, neoclassical economics, social economy, teleological method, trade policy.

JEL classification: B1, B2, B3, B4, F15

Doručeno redakci: 29.4.2017; Recenzováno: 6.5.2017; 12.5.2017; Schváleno k publikování: 20.9.2017

\section{Úvod}

V roce 1919 byl vývoj českého ekonomického učení ovlivněn skutečností, že se Brno proměnilo na vysokoškolské centrum. Již o 20 let dříve podepsal Rakouský císař a uherský král František Josef I. dekret o založení České vysoké školy technické v Brně, která se stala první vysokou školou na Moravě a od podzimu roku 1899 zahájila výuku. V roce 1910 se na této škole habilitoval docentem národního hospodářství Karel Englišs, který na české technice v Brně působil od roku 1911 jako mimořádný profesor. Řádným profesorem se stal v roce 1917. Ukázalo se, že pro vývoj ekonomického myšlení se stal v roce 1912 významným prŕíchod Františka Weyra na českou techniku do Brna. Weyr a Engliš se osobně znali již ze studií a účasti na semináŕích A. Bráfa na pražské Právnické fakultě.

Zákonem z 28. ledna 1919 byla v Brně zř́zena Masarykova univerzita se čtyřmi fakultami. Vedle lékařské, př́rodovědecké a filozofické byla založena i fakulta právnická, čímž v Brně vznikla institucionální platforma pro pěstování a rozvoj ekonomické vědy. Obě výše uvedené osobnosti stály u zrodu univerzity, na kterou přešli při jejím založení. Engliš jako první rektor Masarykovy univerzity, Fr. Weyr jako první děkan Právnické fakulty.

V témže roce 1919 byla zř́zena (zákonem č. 460 ze dne 24. července 1919) Vysoká škola zemědělská v Brně, která si svůj název podržela do roku 1994 (dnešní Mendelova univerzita). Přestože na obou vysokých školách vznikly ekonomické fakulty s výrazným časovým odstupem (Provozně ekonomická fakulta VŠZ v roce 1959 a Ekonomicko-správní fakulta MU až v roce 1991), zapsaly se obě vysoké školy významně do historie a vývoje českého ekonomického myšlení. Zatímco podíl Masarykovy univerzity, resp. K. Engliše a jeho žáků 
vstoupil do širšího povědomí, ${ }^{1}$ skutečnost, že se na rozvoji ekonomického vzdělávání na Vysoké škole zemědělské podílely významné osobnosti ekonomického myšlení, patří k méně známým, nicméně obsahově pozoruhodným skutečnostem.

\section{Emanuel Schindler - žák A. Bráfa a národohospodář}

Rozhodnutím prezidenta republiky ze dne 17. 10. 1919 byl Emanuel Schindler jmenován řádným profesorem národního hospodářství na Vysoké škole zemědělské v Brně a tím vstoupil do počáteční etapy ekonomického vzdělávání nově vzniklého moravského vysokoškolského centra.

E. Schindler se narodil 30. května 1882 v tehdejším Německém Brodě. Studium na gymnáziu započal v Čáslavi a dokončil v Německém Brodě, kde maturoval v roce 1900. Právnická studia zahájil ve Vídni a pokračoval v Praze. Právě studium na pražské právnické fakultě předurčilo jeho další profesní působení. Studia na právnické fakultě zakončil doktorátem Z věd právních v roce 1905 a nastoupil do soudní a advokátní praxe, kde dospěl k rozhodnutí, že se bude plně věnovat národohospodářské vědě. V letech 1906 - 1907 odjel do Paříže, kde studoval na universitě a na École libre des sciences politiques. I v následujícím roce vykonal studijní cestu do Paříže a Londýna, kde se věnoval podrobnému studiu staré literatury o socialismu.

Po návratu zahájil své pedagogické působení jako profesor obchodní nauky a národního hospodářství na obchodní akademii v Praze. V roce 1910 přešel na nově zřízenou královskou českou hospodářskou akademii v Táboře, kde působil jako honorovaný docent. V roce 1915 se stal mimořádným profesorem a $\mathrm{v}$ roce 1916 řádným profesorem pro obor politická ekonomie. V témže roce se habilitoval na právnické fakultě university v Praze pro obor národní hospodářství. Až do zř́izení Vysoké školy zemědělské v Brně pedagogicky působil v Táboře.

V programu VŠZ v Brně na studijní rok 1922 je prof. Schindler uváděn jako přednášející dvousemestrálního povinného předmětu Národní hospodářství. Předmět byl vyučován do roku 1924 ve 2. ročníku studia, poté již pravidelně v 1. ročníku studia. Schindler rovněž vyučoval volitelný předmět Bankovnictví a bursovnictví ve 4. ročníku. (Od roku 1924 Nauka o bankách a bursách). Od nástupu na VŠZ zastával funkci ředitele ústavu politické ekonomie a ve školním roce 1922/23 byl rovněž děkanem hospodářského odboru. Jako národohospodářský odborník byl jmenován členem Československé akademie zemědělské, konkrétně jejího V. (ekonomického) odboru (Bilovský 1936, s. 811).

Na jaře roku 1936 Schindler onemocněl, ale nic nenasvědčovalo blízkému úmrtí. Jak uvedl prof. JUDr. František Bilovský (Bilovský 1936, s. 812), řádný profesor pro právo soukromé, právo veřejné, zemědělské zákony a politiku (v roce 1925/26 rektor VŠZ): „Počátkem října, třebas ne zcela zdráv, zahájil přednášky. Dne 29. ř́ijna nás ohromila zpráva, že od nás odešel navždy. Vysoká škola zemědělská těžce pocit’uje ztrátu muže takových vlastností a zachová jemu trvalou, čestnou památku.“

Po své smrti roku 1936 byl nahrazen ve výuce národního hospodářství profesorem Františkem Zemanem, který byl stoupencem teleologické školy Karla Engliše. Z hlediska pojetí ekonomie se tím končí, zřejmě nejen v Brně, pěstování tradice německé historické školy a její metody v českém ekonomickém myšlení.

\footnotetext{
${ }^{1}$ Blíže o metodě a formování školy např. Vencovský (1997), Fuchs (2000), Fuchs (2012),
} 


\section{Teoretická východiska Schindlerova národního hospodářství}

Formování Schindlerových ekonomických názorů se odehrávalo pod intenzivním vlivem Albína Bráfa, dominující osobnosti českého ekonomického myšlení posledních desetiletí 19. století. Jako mnoho dalších tehdejších studentů pražské právnické fakulty projevil hlubší zájem o studium národohospodářských otázek, který u nich probouzel prof. Bráf. Nejen na přednáškách, ale především $v$ národohospodářském semináři se vytvořily velmi úzké vztahy mezi Bráfem a jeho žáky, kteří se zařadili mezi první významné národohospodáře Československé republiky. Je obecně známo, že Bráf, který představoval v české společnosti výraznou vědeckou, pedagogickou a morální autoritu, poskytoval svým žákům podporu při studiu a kariérním postupu. Aktivně s nimi spolupracoval při hledání pracovních míst. Jak uvádí Krameš (2016, s. 6): „K nejvýznamnějším žákům A. Bráfa patřili zejména Cyril Horáček a Josef Gruber (profesoři politické ekonomie na české pražské univerzitě), Emanuel Schindler (profesor národního hospodářství, finanční vědy a statistiky na Vysoké škole zemědělské v Brně), Josef Drachovský, Vilém Funk (profesoři finanční vědy a finančního práva na pražské univerzitě). “Za nejvýznamnější nositele Bráfova dědictví v Československé republice je možno považovat Karla Engliše, Josefa Macka a Vilibalda Mildschuha. ${ }^{2}$

Díky úzkému kontaktu s žáky, používají někteří autoři i označení Bráfova škola, přesto, že do obsahového vymezení pojmu ekonomická škola schází především charakteristický znak originálního systému ekonomické teorie a tomu odpovídající metodologie. Označením škola je však zdůrazňován vliv na české ekonomické myšlení a na vývoj české společnosti vůbec. Bráf a jeho žáci ovlivňovali hospodářský život české společnosti v posledních desetiletích existence Rakouska a zasáhli i do hospodářského života Československé republiky v období mezi světovými válkami.

Pokud se pokusíme $\mathrm{v}$ dobovém kontextu vyhodnotit zdroje a teoretická východiska Schindlera, musíme zdůraznit skutečnost, že Bráfova soustava názorů (kterou byl Schindler formován) byla vyústěním delší tradice vývoje ekonomického myšlení v českých zemích. Plně se v ní odrážela dobová potřeba ekonomické vědy v české společnosti toužící po národní emancipaci. Proto také přerostla do soustavného pěstování ekonomické vědy v české řeči a zahrnovala i výuku a odbornou výchovu ekonomů. Bráfovy národohospodářské semináře umožňovaly prohloubení národohospodářských znalostí i osvojení si vědeckých metod, ale rovněž jejich aplikace na výběr aktuálních problémů české národní společnosti a zkoumání metodologie ekonomické vědy samotné. Bráfa stál u zrodu národohospodářského odboru studentského spolku Všehrd, na jehož půdě se konaly diskuse $\mathrm{k}$ vybraným problémům, probíraly se stati z děl významných světových ekonomů, utvářela se zde i původní česká ekonomická terminologie. Na základě materiálů z archivu Karlovy univerzity uvádí Krameš (2016, s. 85): „Schindler jako student práv se zúčastnil seminářů profesora Cyrila Horáčka se seminární prací: „Anglická banka“ s prospěchem výborným a profesora Albína Bráfa s prací „Merkantilismus a státní praxe v Rakousku za Leopolda I“. Po absolutoriu, již jako doktor práv, se Schindler roku 1905 zúčastnil Bráfova semináře podruhé s prací na téma: „Celní tarif dvojitý", za kterou obdržel cenu s finanční odměnou. Práce pak byla uveřejněna roku 1907 ve „Sborníku věd státních a právních“.

Jak dokládají obě práce, odnesl si Schindler zvládnutí historické metody i přesvědčení o jejím nezastupitelném významu v ekonomické vědě. Je zrrejmé, že důsledně vychází z pojetí

\footnotetext{
${ }^{2}$ Vztah některých žáků k Bráfovi byl ovšem komplikovanějšíi, ze známějších osobností např. Františsek Čuhel nebo Jan Jaroslav Koloušek.
} 
předmětu, které bylo rozpracováno v úzké spolupráci Josefa Kaizla ${ }^{3}$ a Albína Bráfa. Prosazení historické metody se v českém prostředí opíralo i o osobní Kaizlovu zkušenost, založenou na stipendijním pobytu na univerzitě ve Štrasburku v letech 1876 - 1877. Na tamější univerzitě působila řada předních osobností historické školy, především dominantní osobnost mladší školy G. Schmoller, ale také např. G. F. Knapp a A. Schäffle. Kaizl pod Schmollerovým vedením sepsal spis o dějinách bavorského živnostenského pojištění. Práce byla univerzitou oceněna a vyšla knižně v roce 1879 v Lipsku. Když o tři roky později vychází Kaizlovo Národní hospodářství ${ }^{4}$, je pod výrazným vlivem historické školy, i když Kaizl zdůrazňoval, že posláním spisu je popsat skladbu národohospodářskou jaká je a nikoliv jaká by měla být, př́ípadně jak toho dosáhnout (blíže Kaizl 1883, s. 320). Je to komplexní dílo, které si kladlo za cíl seznámit českou odbornou veřejnost, zejména studující, se základními poznatky národohospodářské vědy. Hospodářství chápe jako promyšlenou činnost člověka, při které jde o co nejúplnější uspokojení potřeb pomocí nejmenšího nákladu. Jde tedy o činnost rozumovou, přičemž ale musí se odlišovat činnost technická - výroba určitého množství statků, určité jakosti, na určitém místě a v určitou dobu, od činnosti ekonomické - což je postup podle zásady hospodárnosti (blíže Kaizl 1883, s. 6). Při výkladu hodnoty je již patrný vliv marginalistické revoluce (resp. rakouské školy). Hodnota je podle Kaizla důležitost (význam), jakou přisuzuje člověk jakémukoliv statku. Když posuzuje náklady na opatření statku, poměřuje je $\mathrm{s}$ užitkem $\mathrm{z}$ jeho použití. Hledá minimum nákladu a maximum užitku. Zdůrazňuje, že hodnota je kategorie nejen psychologická, ale také poměrová (relativní), je výsledkem porovnání. Zdůrazňuje, že cena je peněžním vyjádřením směnné hodnoty statků, ale také, že se utvárí poměrem mezi nabídkou a poptávkou. Zdůrazňuje však, že existují hranice, které nemohou být tímto poměrem překročeny. Jedná se o zřejmý vliv Mengera, když uvádí, že maximální hranicí je nejvyšší platnost užitková, kterou pocituje někdo z kupujících a minimální hranicí ceny je nejnižší platnost nákladová, kterou pocituje někdo z nabídkové strany. Za pozornost pak stojí i zdůraznění, že pro utvoření rovnovážné ceny, musí být splněno několik podmínek, a to především: všichni účastníci trhu si musí počínat tržně, musí být konkurence, musí být umožněno, aby na straně poptávky odstoupili ti, jejichž pocit užitku je chabý, na straně nabídky ti, jejichž pocit nákladový je prŕliš velký (blíže Kaizl 1883, s. 175).

V tomto kontextu propracovává Bráf svoji teoretickou soustavu, kterou si při studiu osvojoval Schindler. V úvodním pojednání o hospodářství zdůrazňuje Bráf, že ve svém pojetí rozumí hospodářstvím především lidskou činností, jejímž cílem je opatřovat ukojení lidských potřeb zevními statky, přičemž člověk se snaží postupovat účelně, aby se dosáhlo prospěchů (užitků) poměrně nejvyšších, obět'mi poměrně nejnižšími. To považuje také za zásadu hospodárnosti (Bráf 1913, s. 1).

Z hlediska přístupu $\mathrm{k}$ národohospodářské vědě se pro Schindlera stává charakteristické naplňování trři cílů, které Bráf $\mathrm{s}$ hospodářskou vědou spojoval a ve svých přednáškách zdůrazňoval.

a) Vysvětlovat a objasňovat konkrétní hospodářské jevy, jejich souvislosti a vztahy. Jedná se tedy o studium historické a popisné, včetně statistiky.

b) Musí se zajímat $\mathrm{o}$ to, co se $\mathrm{v}$ hospodářském dění a $\mathrm{v}$ hospodářstvích pravidelně opakuje, co je různým jevům společné a co je pro ně typické. Hledá pravidelnosti

\footnotetext{
${ }^{3}$ Josef Kaizl (1854 - 1901) je považován za skutečně prvního českého národohospodáře. Narodil se ve Volyni a po maturitě se v roce 1871 zapsal na právnickou fakultu Karlo-Ferdinandovy univerzity v Praze. Studium zakončil v roce 1875 .

${ }^{4}$ Hlavní teoretický spis, vydáno 1883.
} 
(hospodářské zákony) toho co je, stejně jako to dělají vědy př́rodní. Hledat a vysvětlovat zákony je úkolem národohospodářské teorie.

c) Z historického a teoretického poznání lze vyvodit všeobecná pravidla, zásady, maximy pro praktické hospodářské jednání. To je úkolem praktické vědy národohospodářské. Je-li subjektem stát, pak jde o národohospodářskou a finanční politiku (Bráf 1913, s. 14-15).

E. Schindler se stal výjimečnou osobností ve vývoji českého ekonomického myšlení v tom smyslu, že po celý profesní život (až do své smrti 1936) zůstal př́edstavitelem metody historické školy v Československu. Ztotožňoval se s př́stupem mladší německé historické školy, která vycházela ze sociálních hledisek. „Mám za to, že prof. Schindler je jediným českým autorem, který důsledně a vědecky užíval u nás metody historické až do konce svého života.“" (Zeman 1936, s. 812). V této souvislosti je vhodné zdůraznit, že historická škola je tradičně spojována $\mathrm{v}$ českém ekonomickém myšlení s osobností J. Kaizla, zejména vzhledem $\mathrm{k}$ výše uváděným osobním kontaktům s osobnostmi mladší historické školy a tomu odpovídající metodě při výkladu národohospodářské teorie. V ekonomických názorech Schindlera je podle Zemana patrný posun blíže k pozici presentované autory druhé generace mladší historické školy (W. Sombart aj.).

Pokud jde o vlastní Schindlerův přístup, je zřejmé, že reflektuje vyústění obou sporů o metodu, kterých se účastnili př́slušníci mladší historické školy. Průběh a obsahové otázky sporů výrazně přispěly k profilování př́ístupu mladší historické školy. První spor o metodu probíhal mezi G. Schmollerem (dominující osobnost mladší historické školy) a C. Mengerem, (prvním představitelem a zakladatelem nastupující rakouské psychologické školy). Obsahem sporu byla konfrontace mezi abstraktně-deduktivním, racionálním směrem spojeným s marginalistickou revolucí v ekonomii a empiricko-realistickým př́stupem preferujícím popisnou metodu a indukci. Schmoller nakonec připustil oprávněnost abstraktně-deduktivní metody. ${ }^{5}$ Neméně významný druhý spor o metodu se odehrál mezi samotnými představiteli historické školy. Předmětem byla otázka hodnotících soudů. Schmoller a Wagner chápali ekonomii jako etickou a normativní vědu, jejímž hlavním posláním je vypracovat doporučení pro hospodářskou a sociální politiku státu. Na druhé straně Weber a Sombart zdůrazňovali, že předmětem jejího zkoumání musí být to co je a do jejího obsahu nepatří dávat doporučení hospodářské politice (spor souvisí s narůstajícím časovým odstupem od roku 1871, ve kterém se prosazoval př́klon ekonomie k pozitivnímu pojetí neoklasické ekonomie).

I když v př́ípadě Schindlera nemáme k dispozici záznamy přednášek, či ucelený učebnicový výklad národního hospodářství (jako je tomu u J. Kaizla, A. Bráfa i některých žáků, např̀. C. Horáčka, J. Kolouška, aj.) je zřejmé, že pro Schindlera je charakteristické spojování hospodářské stránky s ostatními stránkami společenského života, i hluboké přesvědčení, že tyto stránky spolu souvisí a je nutné je popsat vývojem. To, jak hluboce si Schindler osvojil a prakticky užíval základy historické metody, lze ilustrovat citací z Ročenky Spolku posluchačů zemědělského inženýrství na VŠZ v Brně z roku 1920, kde se ve svém příspěvku věnuje významu studia v cizině. „Vývoj poznání, myšlenky a vědy jest u každého národa stromem, který vyrůstá z jedné půdy; stromem, jehož větvemi jsou jednotlivé obory. Třeba proto jíti dále a věnovat pozornost i dějinnému a myšlenkovému vývoji národa a není na škodu, všimnouti si i jeho nynějších poměrů sociálních a politických. Jsou to vesměs věci, které mají svůj vliv na způsob vědecké myšlenky a práce“ (Schindler 1920, s. 32). K tomu ještě dodává,

\footnotetext{
${ }^{5}$ Pozn. Výchozí konstrukce historické metody v pojetí Roschera je stručně, ale přesně prezentována $\mathrm{v}$ Ingram (1895, s. 170-171).
} 
že uvedené platí větší mírou pro společenské vědy, ale považuje to za platné i pro vědy př́rodní.

Podle E. Schindlera pojednává národohospodářská věda o hospodářském životě jako součásti společenského organismu. V jeho rámci dochází ke spojení hospodářství, práva, etiky i techniky, přičemž společenský organismus je výsledkem vývoje národní kultury a protože samotný národ je produktem dějinného vývoje, nemůže se dle Schindlera hospodářská věda omezit výlučně na zkoumání přítomnosti, ale musí zohledňovat historický vývoj a jednotlivé př́tomné jevy chápat a interpretovat jako výsledky dějinného vývoje. Proto musí být vědou historickou. V tomto kontextu by se mohl Schindlerův př́stup i chápání metody jevit jako prosté a důsledné naplnění původního Roscherova pojetí (viz předchozí odkazy č. 14 a 15). Obsahová sounáležitost s mladší historickou školou je však snadno postižitelná.

Představitelé mladší historické školy zdůrazňovali etický prvek lidského chování a projevovali hluboký zájem o sociální politiku. V roce 1872 založili pod vedením G. Schmollera Spolek pro sociální politiku (Verein für Sozialpolitik), jehož prostřednictvím prezentovali své reformistické postoje. Obecně vycházeli z určující role právních norem v hospodářství, jejichž uvedení do života měl zabezpečit stát, kterému přisoudili významnou roli v národním hospodářství. Výchozí pozice se opírala o Schmollerovo zdůraznění, že ekonomiku je možno rozvíjet pouze na základě využití popisného materiálu, historických faktů a statistických dat. Při zkoumání ekonomických a sociálních problémů využíval poznatky jiných oborů (psychologie, etnografie, antropologie, biologie). Zdůrazňoval relativnost vědeckých představ, úlohu změn ve společenském životě, potřebu realismu a kritiku abstraktních, deduktivních metod ve výzkumu. Zdůrazňoval rovněž, že ve společenských vědách není místa pro matematiku, protože reakce lidské psychiky jsou příliš složitou úlohou pro vyjádření diferenciálním počtem, připouštěl využití statistických dat. Jak bylo uvedeno výše, na základě prvního sporu o metodu došlo i u Schmollera ke korekci v podobě připuštění abstraktně-deduktivní metody. Tento posun měl vliv na postoje A. Wagnera, dalšího z významných autorů, kteří ovlivňovali svými názory Schindlera. Wagner zdůrazňoval snahu školy postupně přecházet od jednostranně induktivní metody k metodě více deduktivní a vytvářet abstraktní a ryze hospodářské pojmy. Přesto i zástupci nejmladší generace (k nejvýznamnějším patřil W. Sombart) odmítají univerzální zákony a zdůrazňují, že charakter ekonomických institucí je podmíněn místně i časově jejich působností. Podle jeho názorů neexistuje univerzální ekonomika, ale můžeme hovořit pouze o ekonomickém řádu (blíže Holman 1999, s. 127 - 129).

Historická škola období Schindlerových studií i odborného vědeckého a pedagogického působení vycházela ze sociálních témat či sociálních aspekti̊ společensko-hospodářských poměrů. Protože se současně jednalo o př́stup, se kterým se již ztotožnil v Bráfově podání, inklinoval k učení mladší historické školy metodou i obsahovými otázkami. Schindler svoji disciplínu nazýval „sociální ekonomie“, nebot’ vedle sobectví se řídí člověk i citem sociálním, proto se musí přihlížet i k tomuto citu. I pro Schindlera je to hlavní důvod, proč stát musí do hospodářství zasahovat. Schindler kladl rovněž důraz na sociologii. Přejímal názor A. Wagnera, že je třeba přejít od výhradně používané induktivní metody k metodě deduktivní.

Zde je možné hledat i odpověd' na otázku př́padného vlivu rakouské školy a její metody. Trvale rostoucí vliv rakouské školy na vývoj moderní ekonomické teorie byl zřejmý a promítal se již do Bráfových vysokoškolských přednášek. Pro postižení možného vlivu je nezbytné zohlednit rozhodující dobový kontext. 
V době Schindlerova působení v Brně, se zde sešlo na třech vysokých školách několik Bráfových žáků, a to v podmínkách, kdy se na Masarykově univerzitě, stejně jako na Vysoké škole zemědělské zahajuje tradice vysokoškolského vzdělávání. A před pedagogy stojí jako klíčová výzvy koncipování kurzů národohospodářské vědy pro nastupující studenty. Složitost situace, dobovou atmosféru, vnitřní pnutí $\mathrm{v}$ oblasti ekonomického myšlení a národohospodářské vědy velmi výstižně popsal s časovým odstupem a díky tomu i nadhledem Vl. Vybral. Když se vracel ke kořenům, ze kterých generace vzešla, uvádí: „Systematickým rámcem, $\mathrm{v}$ němž se Englišovi jako mladému adeptu podávaly výsledky soudobého hospodářského bádání, byla trojdílná koncepce národohospodářských disciplín, které akademická tradice středoevropská spojovala od dob Rauových pod společným názvem „politická ekonomie“, rozpadající se na výklady národohospodářské teorie, národohospodářské politiky a finanční vědy. .... Středoevropské zpracování této teorie respektovalo částečně jednak výsledky bádání historické školy národohospodářské, uplatňující hlavně poznatek o historické podmíněnosti hospodářských institucí kapitalistického řádu a o významném vlivu státu v tomto vývoji, jednak i teoretické výsledky rakouské školy subjektivní hodnoty při výkladu směny, cen, kapitálu a některých ostatních základních jevů hospodářských. ... Tento obsahový eklekticismus byl naukou převládající i v užším českém prostředí národohospodářském. ... eklekticismus byl tu dále pod silným vlivem praktických potřeb národa dospívajícího po obrození literárním a politickém $\mathrm{k}$ obrození národohospodářskému. Máme-li shrnouti naše předválečné pěstitele národního hospodářství pod společný název, nechybíme podstatně, nazveme-li je starou školou, která vedle shora zmíněného eklekticismu hospodářskoteoretického je charakterizována hlavně tím, že do popředí svého naukového zájmu stavěla otázky praktické hospodářské politiky“ (Vybral 1938, s. 381 - 383). Uvedená slova se vztahují plně na celou generaci národohospodářù absolvujících svá studia na přelomu 19. a 20. století, tedy včetně E. Schindlera. Je všeobecně známo, že právě na brněnské právnické fakultě se v úzké symbióze práva a ekonomie propracovala nová teleologická metoda a $v$ té souvislosti se také hovoří o vzniku Brněnské ekonomické školy (blíže Fuchs 2000, s. 482 - 492). Zdá se nezpochybnitelné, že do těchto diskusí E. Schindler nevstoupil a pokud projdeme uvedené ročníky prestižního odborného časopisu, tedy Obzoru národohospodářského, můžeme konstatovat, že se do diskusí nezapojil, ani se k nim nevyjádřil. Ve skutečnosti to znamená, že se $\mathrm{s}$ tímto procesem neztotožnil, i když s hlavními protagonisty byl v pracovním pravidelném kontaktu. Na právnické fakultě byl členem komise pro státní závěrečné zkoušky, s mnohými udržoval osobní kontakty. Důvod byl nepochybně v přehodnocování role a vlivu německé historické školy. Jestliže ze sporů o metodu vyšla mladší historická škola v lepší kondici, pak nyní se stávaly významnými další okolnosti předznamenávající změnu v pojetí národohospodářské teorie.

a) Pro české ekonomické myšlení byl spor o metodu významný i tím, že byl považován za vymaňování se z kamerálního kontextu, kde kameralistika byla vnímána jako reziduum rakouského vlivu. V tomto kontextu je předěl mezi historickou školou a kameralistikou méně výrazný a nabízí řadu podobenství a setrvačností v přístupu.

b) Druhou okolností byla skutečnost, že v 90 . letech 19. století se obsahově rozchází učení rakouské školy, která stála u zrodu marginalistické revoluce a podílela se praktickým užitím metodologického individualismu a teorie mezní užitečnosti na konstituování základů neoklasické ekonomie, s dalším vývojem neoklasické ekonomie.

S vývojem neoklasické ekonomie souviselo omezení šíře i pojetí otázek, kterými by se měla ekonomie zabývat. Tyto okolnosti ovlivňovaly formování české národohospodářské teorie, stejně jako její výukovou presentaci. Ze širší palety vlivů je možno vyzvednout zejména dvě následující okolnosti. 
a) Zvýrazňovala se rostoucí disharmonie mezi př́istupem neoklasické ekonomie, která byla rozpracovávána jako teorie mikroekonomická a postupně narůstajícími problémy s výrazným makroekonomickým rozměrem (nap̌r. otázky měny a kupní síly peněz, vývojové tendence hospodářských cyklů, které motivovaly potřebu propracování makroekonomických aspektů teorie hospodářství).

b) Nepochybně závažnou okolností byla rovněž skutečnost, že vývoj ekonomické teorie neoklasického směru neotevíral prostor $\mathrm{k}$ otázkám role a funkce státu v hospodářství a prostor pro sociální dopady hospodářských procesů. Přitom $\mathrm{v}$ dobovém kontextu bylo $\mathrm{v}$ ekonomickém myšlení hluboce ukotveno přesvědčení o nutnosti narůstající role státu.

Výsledek přehodnocení v Englišově brněnské škole předznamenal již první učební text z roku 1922, kde úvodní pasáže naznačují důvod neakceptovatelnosti a nemožnost Schindlerova ztotožnění se s novým směrováním národohospodářské teorie. Při základním zavádění pojmů ve třetím oddílu „O vědě hospodářské“ je uváděno (Engliš 1922, s. 40): „Někdy bývají zjevy hospodářské označovány jako sociální a věda hospodářská jako speciální věda sociální. Nehledě k tomu, že není uspokojivé odpovědi dosud k tomu, co jest zjev sociální, ani k tomu, které zjevy sociální jsou hospodářské, není pojetí to už proto správné, poněvadž popírá možnost individuálního hospodaření isolovaného člověka, což jest nesprávné. Zajisté mnohé zjevy hospodářské jsou též sociální....., ale ne všechny a též ne nutně." O dvě strany dál pak následuje pojednání, proč nemůže být věda hospodářská konstruována normativně. „Normativní konstrukce vědy hospodářské není možná. Pod zorným úhlem toho, co býti má, co jest povinno, nelze zjevů hospodářských viděti (Engliš 1922, s. 42).“ Již z těchto skromných odvolávek je patrné, co vedlo Schindlera k setrvání na původním, osvojeném př́ístupu. Je doloženo, že Schindler studoval spis C. Mengera, s učením rakouské školy se pečlivě seznámil, navštěvoval i knihovnu C. Mengera. Přesto metodu rakouské školy neužil. Zde je možno souhlasit s hodnocením F. Zemana (Zeman 1936, s. 813), který nastoupil po Schindlerově smrti na uvolněný post a patřil ke stoupencům teleologické metody, když uvedl: „Poněvadž prof. Schindler rakouskou školu znal a přece její metody neužil, možno souditi, že se tak stalo po zralé úvaze." Schindler chápal svoji hospodářskou vědu nejen jako nauku historickou, ale také sociální.

\section{Schindlerovo dílo}

Schindlerovo dílo představuje 10 spisů vydaných v období 1904 až 1934 . Již prvním spisem si vydobyl ohlas a uznání. Jednalo se o práci zpracovanou v Bráfově semináŕi a věnovanou dějinám obchodu. Spis Merkantilismus a státní praxe v Rakousku za Leopolda I. je důsledně zpracován historickou metodou a v plném rozsahu byl publikován již v roce 1904 v prestižním Obzoru národohospodářském (roč. IX, 35 stran). Současně je nejznámějším Schindlerovým spisem. Soustředí se na identifikaci překážek zavádění merkantilistické politiky a ilustruje i specifika středoevropského (kamerálního) př́stupu. Čtenář má možnost blíže pochopit postoje i činy tradičních učebnicových představitelů rakouského merkantilismu (Becher, Hornick, Schröder aj.).

I druhý spis vznikl v na půdě Bráfova semináře, kterého se účastnil podruhé, již jako doktor práv. Jednalo se o spis „Celní tarif dvojity“", za kterou obdržel cenu s finanční odměnou. Práce pak byla uveřejněna roku 1907 ve Sborníku věd státních a právních. Schindlerova práce potvrzuje hlubší zájem o obchodní politiku. Zdůrazňuje, že dvojitý tarif vzniká ze snahy po celní autonomii, jako výraz snahy zajistit vliv na úpravu styku s cizinou. Zde popisuje zavedení dvojího tarifu v různých zemích a odvozuje závěr o dopadech na jednotlivé země. 
Třetí publikací je Kritika spisu: A. Sartorius Freiherr von Waltershausen. Das volkswirschaftliche Systém der Kapitalanlage im Auslende. Kritika byla publikována v roce 1908 ve Sborníku věd právních a státních. Její těžiště je vedeno z pozice, že vývoz kapitálu musí být v souladu s cíli, které sleduje národní hospodářská politika v mezinárodní oblasti.

Čtvrtým spisem bylo Zemědělství a moderni vývoj hospodářský. Schindler pojednává o postavení zemědělství v moderním hospodářství a zdůvodňuje nezbytnost komercializace v celém sektoru. Odtud odvozuje, že nutným předpokladem je, aby zemědělec zvládl nejen moderní techniku, ale získal také potřebné znalosti obchodní.

Pátá publikace je nejrozsáhlejší a také dokresluje, že odborný zájem E. Schindlera se soustřed'oval především na dva tematické okruhy. Těmi byly socialismus a obchodní politika. Oběma tematickým okruhům se celoživotně věnoval. Spis Socialismus a obchodní politika je habilitační prací, na jejímž základě se v roce 1916 habilitoval na právnické fakultě Karlovy univerzity. Spis s podtitulem Studie historická a kritická vyšel v roce 1914. Vydavatelem a nakladatelem byl Sborník věd právních a státních. Práce má 155 stran. Jak uvádí Schindler, prvním podnětem k sepsání byla otázka domnělé příbuznosti celní ochrany a socialismu, což bylo následně rozšířeno na hledání odpovědi na otázku stanoviska socialisti̊ k zahraničnímu obchodu a obchodní politice. Práce má logickou strukturu vypovídající o systematickém př́stupu z pozice historické metody. První část je věnována analýze socialismu a opírá se o kritickou analýzu jednotlivých př́stupů v kontextu vývoje kapitalismu. Poměrně výrazný prostor je věnován znaku antikapitalismu, přičemž hledá paralely, ale také zdůrazňuje rozdíly $\mathrm{v}$ tomto rysu, v závislosti na tom, kdo je nositelem. Zda vrstva, která byla nastupujícím kapitalismem potlačena, nebo vrstva, která se v kapitalismu formuje, jak ř́ká Schindler, na základě moderního námezdního poměru. „A právě tak jak v buržoasii v důsledku jejího subjektivního postavení si kapitalismus vytvář́ vrstvu, která jej representuje, tak zase v proletariátu vytváŕí vrstvu, která mu odporuje. ... Odpor ten vzniká tu právě tak, jak svého času vznikl proti kapitalismu odpor ve vrstvách starých. Antikapitalismus proletariátu, poněvadž z jiného podkladu a prostředí vyrůstá, jest ovšem jiného obsahu a rázu než antikapitalismus starých vrstev“ (Schindler 1914, s. 18). Odtud se dopracovává k vymezení chápání pojmu, když zdůrazňuje, že tento odpor si vytváří vlastní duchovní myšlenkovou reakci proti kapitalismu a tou rozumí socialismus. Poté následuje podrobný rozbor vývoje názorů označovaných jako socialistické s důrazem na dva aspekty, a to vlastnictví a také princip rozdělování, zejména v kontextu tzv. bezpracných důchodů. Schindler $(1914$, s. $37-$ 41) dospívá k závěrům, ve kterých je zdůrazněno:

a) Socialismus je svojí podstatou názorem negativním, nebot' jeho obsah a směr jsou dány poměry, které neguje. Tím také vysvětluje slabost a neujasněnost positivního programu socialistů.

b) Jakmile dochází k propracování positivního programu, ukazuje Schindler, že je to provázeno vzdalováním se od platformy, která tvoří základ pro jeho požadavky negativní. Se znalostí jednotlivých interpretací zde dává do kolize požadavky plného výnosu práce a požadavek distribuce (rozdělování) na základě práce event. na základě potřeb.

c) Navíc dospěl i k charakteristice, že socialismus je svojí podstatou kosmopolitický a upozorňuje, že národní socialismus je protimluv (contradictio in adjecto). Přibližně deset let poté se tato myšlenka stane pro německé prostředí neakceptovatelná.

Za zdůraznění stojí také pasáže, ve kterých je analyzován vztah socialismu k soukromému vlastnictví, kde dospívá k závěru, že socialismus odmítá soukromé vlastnictví, pokud je zdrojem bezpracných důchodů, nikoliv obecně. 
Druhá část pojednává o socialismu a zahraničním obchodě. Je znovu důsledně založena na historické metodě a vyúst'uje do presentace opírající se o názory Hildebranda, Hilferdinga, Kautského a Marxe, aby se dospělo k obdobným kolizím, jako v předchozí části. Tedy co to bude znamenat pro princip rozdělování, když se bude mezinárodní směna odehrávat na principu stejné množství práce za stejné množství práce (tedy tradiční princip ekvivalentní směny). A to s vědomím, že na výrobu téhož nepotřebují jednotlivé země (oblasti, výrobci atd.) stejné množství práce.

Závěrečná část pojednává o vztahu socialismu k obchodní politice. Těžištěm je vztah liberalizace mezinárodního obchodu a celní ochrany a na to následující analýza názorů teoretiků socialismu. Pasáž je pro čtenáře komplikovanější tím, že jsou do kontextu vnášeny i názory autorů, kteří chápou socialismus odlišným způsobem (Bastiat, List, ale také např. Pareto). Završeno je to citací stanoviska sociálně-demokratické strany německé přijatého na sjezdu ve Stuttgartu 1898. Rozborem dospěl Schindler k závěru, že „sráží se tu ohled na přítomnost - taktika s ohledem na vývoj mezd - s revolučním pojetím obchodní politiky“ (Schindler 1914, s. 155). Tím se rozumí vliv obchodní politiky na urychlení vývoje kapitalismu a zostření rozporů. Zde Schindler dospívá k závěru, že nelze akceptovat běžně presentovaný názor odborné literatury, ztotožňující socialismus s celní ochranou.

Jako šestou publikací uvádí $\mathrm{F}$. Zeman habilitační přednášku na téma Organizační síly př́tomného hospodářství (1916). ${ }^{6}$ Podle Zemana jsou jako síly organizační v hospodářském řádu označeny podnikatelství a princip veřejnohospodářský. Jedná se o síly, které mohou působit proti sobě, nicméně Schindler vyvozuje své přesvědčení, že kolektivní hospodaření nemůže vytlačit podnikatelství. Je možno konstatovat, že v duchu Wagnerovy tradice dospívá k závěru, že pro budoucnost bude typické, že oba principy se budou kombinovat.

Sedmá publikace Ke snahám o celně-politické sblížení rakouskoněmecké (1916) završuje pojednání o obchodních otázkách a obchodní politice předchozích prací, i když je obsah vztažen ke specifickému problému. V úvodní části uplatňuje historický př́stup a ilustruje slábnutí tendence k celně-politickému sbližování jako důsledek prosazování volného obchodu v obchodní politice evropských států. S osmdesátými léty 19 . století spojuje obrat v obchodní politice ve prospěch celní ochrany, jako důsledek dvou hlavních vlivů: „nebezpečí zvláště zámořské soutěže zemědělské a jí způsobená krize v zemědělství a konečně vývoj tíhnoucí ke vzniku a konsolidaci velkých celků hospodářských" (Schindler 1916, s. 6). V této souvislosti zdůrazňuje, že v pozadí celněpolitických snah o sbližování ,je vzrůstající sklon po tvoření a konsolidaci velkých světových hospodářských celků, tíhnoucích $\mathrm{k}$ hospodářské výlučnosti a hospodářské soběstačnosti““ (Schindler 1916, s. 8). Je zajímavé, že v uvedeném integračním kontextu vyslovuje i představu: „Je přirozené, že při dnešní souvislosti života hospodářského a politického by se vývoj ten neomezil jen na pole hospodářské, nýbrž přešel by i na pole politické. Vznik velkých světových hospodářských celků by současně znamenal i vznik světových států, vznik nového typu světových velmocí“ (Schindler 1916, s. 10 - 11). Druhá část studie je věnována podstatě celně politického sblížení.

Rozlišuje čtyřri základní formy:

a) celní jednotu (spolek), která je nejsilnější formou. Spojená území s jednotným celním zákonodárstvím a jediným celním tarifem navenek.

\footnotetext{
${ }^{6}$ Zřejmě nevyšla v tištěné podobě a je dostupná v archivu Karlovy univerzity. Habilitační ř́zení proběhlo na právnické fakultě.
} 
b) celní svaz opírající se o jednotný celní tarif navenek a uvnitř jsou uchována nižší vnitřní cla (jako př́klad uvádí vztah Rakouska a Uherska po roce 1850).

c) přednostní systém - zúčastněné státy mají vlastní celní tarify, ale navzájem si poskytují preferenční výhody, které jsou jiným státům nedosažitelné.

d) celně-politická dohoda, jako nejslabší forma, představuje přechod ke smlouvě tarifové, ale mezi zúčastněnými zeměmi je užší vztah.

Poté analyzuje problémy politické, které souvisí především se vzdáním se samostatnosti a volnosti a přesunem kompetence na společné orgány. Mezi hospodářskými problémy uvádí především rozdílnou úroveň hospodářského rozvoje a také problémy hospodářské politiky (zejména otázky měnové, finanční a daňové, dopravní, sociálněpolitické a kartelové). Je možno konstatovat, že se znalostí problematiky zkoumá dopady celní jednoty a aplikace klausule nejvyšších výhod na jednotlivé hospodářské jevy, jako je domácí výroba, měna, ale rovněž politický kontext a dopady na obchodní politiku. Zvláštní pozornost věnuje otázce sblížení v podmínkách nestejné úrovně rozvoje a dospívá $\mathrm{k}$ závěru, že stát $\mathrm{s}$ vyspělejší úrovní technického rozvoje nezískává ze sblížení prospěch.

Další tři studie jsou orientovány k jiným obsahovým otázkám. Především Zákonodárná činnost prvního Národního shromáždění Československé republiky v oboru zemědělství (publikováno v r. 1920 v Zemědělské politice). Schindler řeší otázku pozemkové reformy a podmínek jejího úspěšného završení. Doporučuje užít anglických zkušeností. Devátá práce jsou zkušenosti ze studijní cesty do Francie. Publikováno v r. 1921 v Zemědělském školství a výzkumnictví pod názvem Hospodářské školství ve Francii. V závěrečné práci z roku 1932 s názvem Kapitál, je obsahem vymezení kapitálu jako dispoziční síly nad statky. V Schindlerově pojetí se jedná o majetku, který je užíván výdělkově. Je to pojetí, které odpovídá tradičnímu chápání (hodnota, která se zhodnocuje, resp. hodnota, která se vydává za účelem zhodnocení). V Schindlerově formulaci je však zdůrazněna role kapitálu ve smyslu kapitálového statku v soudobé terminologii.

\section{Závěr}

Prof. Emanuel Schindler patří mezi ty žáky prof. A. Bráfa, kteří se významně podepsali pod historii rozvoje národohospodářské teorie v nově vzniklé Československé republice. Všichni tehdejší národohospodáři vycházeli ze základů národohospodářské teorie, jak jim byly presentovány při studiích na právnické fakultě Karlo-Ferdinadovy univerzity v Praze. Proces osamostatnění a rozvoj vysokého školství v podmínkách nově vzniklé republiky probíhal v období významných proměn ekonomické teorie ve světě, které předznamenávaly oslabení pozice učení historické školy, o které se Bráfův systematický výklad opíral a jímž byla nastupující generace národohospodářů v českých zemích ovlivněna. Je pochopitelné, že rozvoj národohospodářské teorie nabyl různých podob, $\mathrm{v}$ závislosti na tom, se kterými proudy ekonomické teorie se jednotliví národohospodáři ztotožnili. Od výkladů důsledně liberálních a pozitivních, přes př́ístupy, opírající se o liberalismus a metodologický individualismus, ale zohledňujících sociální aspekty hospodářského dění, až k přístupům obsahujícím především vize různých sociálních a socialistických přeměn. V této široké paletě přístupů se Schindler vyznačoval ztotožněním se s tradicí historické metody a tomu odpovídajícímu pojetí předmětu národního hospodářství. Je nutno uvést, že se svojí interpretací řadil do proudu nejmladší generace historické školy, která se již zbavila jednostranné preference empiricko-popisných a induktivních postupů, opírajících se o historické paralely. Byl hluboce přesvědčen, že nejen v národohospodářské vědě, ale také $\mathrm{v}$ jejím zpř́stupňování studentům, je nutno pojmy národohospodářské vědy vysvětlovat prostřednictvím vývoje. Podle Schindlera však stále 
platí, že vedle sobectví se člověk řídí i citem sociálním, a proto je nutno přihlížet i $\mathrm{k}$ tomuto citu. Je to důvod, proč musí také stát hospodářství ovlivňovat. Tyto charakteristiky nenalézal v akceptovatelné podobě či kontextu v proměnách, kterými ekonomie procházela. Proto zřejmě upřednostnil tradiční, vnitřně konzistentní a praxí ověřený přístup k rozvíjení ekonomického myšlení a kvalitních ekonomických znalostí svých studentů.

\section{Literatura}

[1] BILOVSKÝ, F., 1936. Život a činnost prof. Dr. Em. Schindlera. Věstník Československé akademie zemédělské. Ročník 16.

[2] BRÁF, A., 1913. Národohospodářská theorie. Spisy Dra. Albína Bráfa. Sv. I. Nákladem Sborníku věd právních a státních. Praha.

[3] BRÁF, A., 1914. Národohospodářská politika. Spisy Dra. Albína Bráfa. Sv. II. Nákladem Sborníku věd právních a státních. Praha.

[4] ENGLIŠ, K., 1922. Základy hospodářského myšlení. Nakladatelství Barvič a Novotný. Brno.

[5] FUCHS, K., 2000. Brněnská Englišova škola - k problému metody. Politická ekonomie, 48(4), 482-492. ISSN 0032-3233.

[6] FUCHS, K. a J. LISÝ, 2009. Dějiny ekonomického myšlení [online]. 1 vyd. Brno: Masarykova univerzita, Elportál. Dostupné z: $<$ http://is.muni.cz/elportal/?id=837102>. ISSN 1802-128X.

[7] FUCHS, K., 2012. Odkaz osobnosti jako příspěvek k aktuálním teoretickým otázkám. Acta academica karviniensia, 12(3), 5 - 13. ISSN 1212-415X.

[8] HOLMAN, R. A KOL., 1999. Dějiny ekonomického myšlení. Praha, C. H. Beck. ISBN 80-7179-238-1

[9] INGRAM, J. K., 1895. Dějiny vědy národohospodářské. Společným nákladem „Rozhledů“ a Spolku českých právníků „Všehrd“. V Praze a Chrudimi.

[10] KAIZL, J., 1883. Národní hospodářství. Pro studium akademické i soukromé v systematickém pořadu. Praha: Nákl. J. Fořta, tiskem Jos. R. Vilímka.

[11] KRAMEŠ, J., 2016. Profesor Albin Bráf a jeho žáci (česká národohospodářská škola Bráfova). Studie Národohospodářského ústavu Josefa Hlávky. Praha. 2016. ISBN 97880-88018-08-7

[12] SCHINDLER, E., 1904. Merkantilismus a státní praxe v Rakousku za Leopolda I. Obzor národohospodářský. Roč. IX. Praha.

[13] SCHINDLER, E., 1914. Socialismus a obchodní politika. Praha. Bursík a Kohout.

[14] SCHINDLER, E., 1920. Studium v cizině. Ročenka Spolku posluchačů zemédělského inženýrství na vysoké škole zemědělské v Brně. Nákladem Spolku posluchačů. 1920.

[15] SCHINDLER, E., 1916. Ke snahám o celněpolitické sbližení Rakouskoněmecké. Nákladem Fr. Řivnáče, knihkupce České university Karlo-Ferdinandovy a c.k. České vysoké školy technické. Praha.

[16] VENCOVSKÝ, F., 1997. Dějiny českého ekonomického myšlení do roku 1948. Masarykova universita, Brno. ISBN 80-210-1624-8

[17] VYBRAL, V., 1938. První soustava národního hospodářství. Obzor národohospodářrký. 43(6). $381-399$ 
[18] VYBRAL, V., 1930. Problematika principu hospodárnosti v hospodářské teorii. Sborník prací k poctě 50. narozenin dra K. Engliše. Praha - Brno, Orbis. 93 - 143.

[19] ZEMAN, F., 1936. Vědecké práce prof. Dr. Em. Schindlera. Věstník Československé akademie zemědělské. Ročník 16. 